\begin{tabular}{r|r|} 
J. Tjiptabudy, Kebijakan Pemerintah Dalam.................... & 1 \\
Jurnal Sasi Vol.16. No.3 Bulan Juli - September 2010 &
\end{tabular}

\title{
KEBIJAKAN PEMERINTAH DALAM UPAYA MELESTARIKAN NILAI-NILAI PANCASILA DI ERA REFORMASI
}

\author{
Oleh: J. Tjiptabudy
}

\begin{abstract}
Pancasila is the philosophy, the Indonesian state ideology, which means that the Pancasila as a source of inspiration and source of solutions to the nation's problems. In a development in the reform era of pure values contained in Pancasila termaknai not in the life of nation and state. This is what lies behind the author to see how government policies in an effort to preserve the values of Pancasila in the reform era. The results obtained that the translation of Pancasila, which can be used as guidance in the life of nation and state are necessary in the current reform era. Pancasila seems to have been completely forgotten by the various groups in society, although formally. Therefore the government should act in accordance with the values of Pancasila itself Every precepts of Pancasila should be internalized and implemented, government policies should be in accordance with the application of the principles of Pancasila. Does the government have to be firm and fast in ensuring its citizens carry out this first principle of religious life in peace without any confusion in the run his religion from interference deviant teachings, whether the government has made regulations in which the moral attitude of humanity based on the absence of interest groups, whether the government has been able to overcome all understand class, ethnicity, tribe, race, religion or class of individuals that can not be sharpened into conflict and hostility, but it makes a difference who becomes a force for unity of this nation, whether the people led by the wise men in making decisions together unutuk public interest. And lastly whether the government is providing justice for every citizen in the form of welfare, security, assistance, subsidies, and a chance to live without any distinction of rights.
\end{abstract}

Keywords: Government Policy, Pancasila

\section{A. LATAR BELAKANG.}

Pancasila yang merupakan falsafah Negara Indonesia, pada era reformasi seakan-akan mulai tersingkir di dalam kehidupan berbangsa dan bernegara. Nilai-nilai Pancasila yang terkandung di dalam sila-silanya menjadi tidak termaknai dengan baik dalam pelaksanaan kehidupan berbangsa dan bernegara. Hal itu terjadi karena Pancasila bagi sebagian masyarakat baru sebatas hal yang mempengaruhi pola perasaan dan pola pikir, tetapi belum sampai ke perilaku kesehariannya atau pola tindakannya, sehingga berakibat pula pada rendahnya ketahanan kita terhadap pengaruh luar yang mengedepankan kebutuhan materiil.

Mengapa hal ini bisa terjadi ? padahal

Pancasila telah menjadi dasar Negara Republik Indonesia selama 1966 tahun. Apakah Pancasila yang merupakan Falsafah bangsa dan dasar Negara selama ini telah 
\begin{tabular}{r|r|} 
J. Tjiptabudy, Kebijakan Pemerintah Dalam .................... & 2 \\
Jurnal Sasi Vol.16. No.3 Bulan Juli - September 2010 &
\end{tabular}

didegradasi oleh kebijakan pemerintah dalam masa reformasi sekarang ini?

Pasca reformasi negeri ini bak sebuah muara bagi semua ideologi dan pemikiran yg lambat laun justru bertolak belakang dengan ideologi pancasila itu sendiri. Mulai dari fundamentalis hingga liberalis. Semua saling berperan dalam membentuk cara berfikir bangsa ini. apresiasi dari ideologi-ideologi tersebut sudah sangat mempengaruhi dalam kehidupan berbangsa dan bernegara. pancasila dan nilai-nilai dasarnya sudah di tinggalkan bahkan pendidikannya dan realisasinya dalam dunia akademis-pun mulai ditiadakan entah berawal dari mana dan kapan hal itu terjadi.

Dalam rapat dengar pendapat dengan Komisi I DPR, pada bulan juni 2010, Gubernur Lembaga Ketahanan Nasional (Lemhanas) Muladi menyatakan bahwa kesadaran dan penghayatan akan pentingnya Pancasila sebagai ideologi dan pandangan hidup bangsa semakin menipis, terutama di kalangan elit bangsa. Hal tersebut sebagai akibat adanya keinginan perubahan di berbagai aspek kehidupan yang cenderung menimbulkan penyimpangan kebiasaan. Menurut Sekretaris Jenderal Dewan Ketahanan Nasional, Muhammad Yasin, sejak awal reformasi, pamor Pancasila mengalami kemunduran sehingga nilai-nilai dasar Pancasila mengalami degradasi dalam pelaksanaannya.

setelah berbagai persoalan muncul berkaitan dengan implementasi nilai-nilai Pancasila, akhir-akhir ini pemerintah dengan tergesa-gesa mulai mencoba melakukan sosialisasi Pancasila. Ketua MPR Taufiq Kiemas untuk kesekian kali kembali mengemukakan upayanya bersama MPR untuk mensosialisasikan empat pilar berbangsa, yaitu Pancasila, UUD 1945, Negara Kesatuan Republik Indonesia (NKRI), dan Bhinneka Tunggal Ika.

Sehubungan dengan hal tersebut maka pada penulisan ini dicoba dibahas kebijakan pemerintah di dalam upaya melestarikan nilai-nilai Pancasila di era reformasi

\section{B. PEMBAHASAN}

\section{Kesepakatan Falsafah Pancasila}

para pendiri bangsa telah menyepakati falsafah kenegaraan yang berfungsi sebagai common platforms di antara sesama warga masyarakat dalam konteks kehidupan bernegara. Prinsip dasar tersebut adalah Pancasila yang meliputi lima dasar, yaitu (1) ke-Tuhanan Yang Maha Esa, Kemanusiaan Yang Adil dan Beradab, (3) Persatuan Indonesia, (4) Kerakyatan Yang Dipimpin oleh Hikmat Kebijaksanaan dalam Permusyawaratan/ Perwakilan, dan (5) Keadilan Sosial bagi Seluruh Rakyat Indonesia.

Selain itu Pancasila juga disepakati sebagai dasar Negara bagi Negara kesatuan Republik Indonesia. Pancasila memenuhi syarat sebagai dasar negara bagi Negara Kesatuan Republik Indonesia dengan alasan sebagai berikut:

1. Pancasila memiliki potensi menampung keadaan pluralistik yang dialami oleh bangsa Indonesia, ditinjau dari keanekaragaman agama, suku bangsa, adat budaya, ras, golongan dan sebagainya. Sila pertama Ketuhanan Yang Maha Esa, menjamin kebebasan bagi warganegara untuk beribadah sesuai dengan agama dan keyakinannya. Sementara itu Sila ketiga persatuan Indonesia, mengikat keanekaragaman tersebut di atas dalam suatu kesatuan bangsa dengan tetap menghormati sifat masing-masing seperti apa adanya.

2. Pancasila memberikan jaminan terealisasinya kehidupan yang pluralistik, dengan menjunjung tinggi dan menghargai manusia sesuai dengan harkat dan 
martabatnya sebagai makhluk Tuhan secara berkeadilan, disesuaikan dengan kemampuan dan hasil usahanya. Hal ini ditunjukkan oleh sila kedua yaitu Kemanusiaan yang adil dan beradab.

3. Pancasila memiliki potensi menjamin keutuhan Negara Kesatuan Republik Indonesia yang terbentang dari Sabang sampai Merauke, yang terdiri atas ribuan pulau. Sila ketiga Persatuan Indonesia memberikan jaminan bersatunya bangsa Indonesia.

4. Pancasila memberikan jaminan berlangsungnya demokrasi dan hak asasi manusia sesuai dengan budaya bangsa. Hal ini dijamin oleh sila keempat Pancasila yakni Kerakyatan yang dipimpin oleh hikmat kebijaksanaan dalam permusyawaratan/perwakilan.

5. Pancasila menjamin terwujudnya masyarakat yang adil dan sejahtera. Sila kelima Keadilan sosial bagi seluruh rakyat Indonesia merupakan acuan dalam mencapai tujuan tersebut.

\section{Prinsip dan Nilai yang terkandung dalam Pancasila}

\section{a. Prinsip yang terdapat dalam Pancasila}

Dalam pidatonya pada tanggal 1 Juni 1945, Bung Karno menyebut sila-sila dalam Pancasila adalah prinsip-prinsip kehidupan bangsa Indonesia. Pancasila dalam bahasa Inggris disebut the five principles. Dengan demikian maka sila-sila dalam Pancasila itu memberi corak pada pola fikir dan pola tindak bangsa Indonesia dalam menghadapi segala permasalahan hidupnya.

Prinsip Ketuhanan Yang Maha Esa, memberikan acuan bahwa dalam pola fikir, sikap dan tindak bangsa Indonesia harus mengarah pada prinsip yang terkandung di dalamnya, antara lain terwujudnya keselarasan atau harmoni dan kelestarian alam semesta. Orang bebas berfikir, bebas berusaha, namun sadar dan yakin bahwa akhirnya yang menentukan segalanya adalah Tuhan Yang Maha Esa (Man proposes, God disposes), sehingga manusia rela dan ikhlas diatur. Dalam menentukan suatu pilihan tindakan, seseorang memiliki kebebasan, namun kebebasan tersebut harus dipertanggungjawabkan, dan harus menerima akibat dari pilihan tindakannya.

Prinsip Kemanusiaan yang Adil dan

Beradab memberikan acuan bahwa dalam olah fikir, olah rasa, dan olah tindak, manusia selalu mendudukkan manusia lain sebagai mitra, sesuai dengan harkat dan martabatnya. Hak dan kewajibannya dihormati secara beradab. Dengan demikian tidak akan terjadi penindasan atau pemerasan. Segala aktivitas bersama berlangsung dalam keseimbangan, kesetaraan dan kerelaan.

Prinsip Persatuan Indonesia, memberikan acuan bahwa pola fikir, sikap dan tindak bangsa Indonesia harus mengarah pada keutuhan dan kokohnya Negara Kesatuan Republik Indonesia. Kita mengaku bahwa negara kesatuan ini memiliki berbagai keanekaragaman ditinjau dari segi agama, adat, budaya, ras, suku dan sebagainya, yang harus didudukkan secara proporsional dalam negara kesatuan. Dalam hal terjadi konflik kepentingan, maka kepentingan bangsa diletakkan di atas kepentingan pribadi, kelompok, golongan dan daerah.

\section{Prinsip Kerakyatan yang dipimpin} oleh hikmat kebijaksanaan dalam Permusyawaratan/Perwakilan, memberikan petunjuk bahwa dalam berfikir, bersikap dan bertingkahlaku, yang berdaulat dalam negara Republik Indonesia adalah seluruh rakyat, sehingga rakyat memiliki kedudukan terhormat dalam kehidupan bermasyarakat, berbangsa dan bernegara. Aspirasi rakyat menjadi pangkal tolak penyusunan kesepakatan bersama dengan cara musyawarah/perwakilan. Apabila dengan 
\begin{tabular}{r|r|} 
J. Tjiptabudy, Kebijakan Pemerintah Dalam ..................... & 4 \\
Jurnal Sasi Vol.16. No.3 Bulan Juli - September 2010 &
\end{tabular}

musyawarah tidak dapat tercapai kesepakatan, dapat dilakukan pemungutan suara. Setiap keputusan hasil kesepakatan bersama mengikat semua fihak tanpa kecuali, dan semua fihak wajib melaksanakannya.

Prinsip Keadilan sosial bagi seluruh rakyat Indonesia memberikan acuan bagi olah fikir, olah sikap dan olah tindak harus mengarah pada terwujudnya kesejahteraan lahir dan batin yang berkeadilan sosial bagi seluruh rakyat Indonesia tanpa kecuali. Kesejahteraan harus dapat dirasakan oleh seluruh lapisan masyarakat dan merata di seluruh daerah, dihindari terjadinya kesenjangan yang mencolok.

\section{b. Nilai yang terdapat dalam Pancasila}

Dari konsep dan prinsip yang terdapat dalam Pancasila, dapat ditemukan nilai yang menjadi tujuan bangsa Indonesia, dan ingin diwujudkan dalam kehidupan masyarakat berbangsa dan bernegara. Nilai tesebut antara lain adalah:

1. Kedamaian, adalah situasi yang menggambarkan tidak adanya konflik dan kekerasan. Segala unsur yang terlibat dalam suatu proses sosial yang berlangsung secara selaras, serasi dan seimbang, sehingga menimbulkan keteraturan, ketertiban dan ketenteraman. Segala kebutuhan yang diperlukan oleh manusia dapat terpenuhi, sehingga tidak terjadi perebutan kepentingan. Hal ini akan terwujud bila segala unsur yang terlibat dalam kegiatan bersama mampu mengendalikan diri.

2. Keimanan, adalah suatu sikap yang menggambarkan keyakinan akan adanya kekuatan transendental yang disebut Tuhan Yang Maha Esa. Dengan keimanan manusia yakin bahwa Tuhan menciptakan dan mengatur alam semesta. Apapun yang terjadi di dunia adalah atas kehendak-Nya, dan manusia wajib untuk menerima dengan keikhlasan.

3. Ketaqwaan, adalah suatu sikap berserah diri secara ikhlas dan rela kepada Tuhan Yang Maha Esa, bersedia tunduk dan mematuhi segala perintah-Nya serta menjauhi segala larangan-Nya.

4. Keadilan, adalah suatu sikap yang mampu menempatkan makhluk dengan segala permasalahannya sesuai dengan hak dan kewajiban serta harkat dan martabatnya secara proporsional diselaraskan dengan peran fungsi dan kedudukkannya.

5. Kesetaraan, adalah suatu sikap yang mampu menempatkan kedudukan manusia tanpa membedakan jender, suku, ras, golongan, agama, adat dan budaya dan lain-lain. Setiap orang diperlakukan sama di hadapan hukum dan memperoleh kesempatan yang sama dalam segenap bidang kehidupan sesuai dengan potensi dan kemampuan yang dimilikinya.

6. Keselarasan, adalah keadaan yang menggambarkan keteraturan, ketertiban dan ketaatan karena setiap makhluk melaksanakan peran dan fungsinya secara tepat dan proporsional, sehingga timbul suasana harmoni, tenteram dan damai. Ibarat suatu orkestra, setiap pemain berpegang pada partitur yang tersedia, dan setiap pemain instrumen melaksanakan secara taat dan tepat, sehingga terasa suasana nikmat dan damai.

7. Keberadaban, adalah keadaan yang menggambarkan setiap komponen dalam kehidupan bersama berpegang teguh pada peradaban yang mencerminkan nilai luhur budaya bangsa. Beradab menurut bangsa Indonesia adalah apabila nilai yang terkandung dalam Pancasila direalisasikan sebagai acuan pola fikir dan pola tindak.

8. Persatuan dan Kesatuan, adalah keadaan yang menggambarkan masyarakat 
majemuk bangsa Indonesia yang terdiri atas beranekaragam komponen namun mampu membentuk suatu kesatuan yang utuh. Setiap komponen dihormati dan menjadi bagian integral dalam satu sistem kesatuan negara-bangsa Indonesia.

9. Mufakat, adalah suatu sikap terbuka untuk menghasilkan kesepakatan bersama secara musyawarah. Keputusan sebagai hasil mufakat secara musyawarah harus dipegang teguh dan wajib dipatuhi dalam kehidupan bersama.

10. Kebijaksanaan, adalah sikap yang menggambarkan hasil olah fikir dan olah rasa yang bersumber dari hati nurani dan bersendi pada kebenaran, keadilan dan keutamaan. Bagi bangsa Indonesia hal ini sesuai dengan nilai yang terkandung dalam Pancasila.

11. Kesejahteraan, adalah kondisi yang menggambarkan terpenuhinya tuntutan kebutuhan manusia, baik kebutuhan lahiriyah maupun batiniah sehingga terwujud rasa puas diri, tenteram, damai dan bahagia. Kondisi ini hanya akan dapat dicapai dengan kerja keras, jujur dan bertanggungjawab.

Dengan memahami konsep, prinsip dan nilai yang terkandung dalam Pancasila, yang tentu masih akan berkembang sesuai dengan dinamika kehidupan bangsa Indonesia, permasalahan berikutnya adalah bagaimana konsep, prinsip dan nilai tersebut dapat diimplementasikan secara nyata dalam berbagai bidang kehidupan.

\section{Kebijakan Pemerintah Dalam Upaya Melestarikan Nilai-Nilai Pancasila}

Apapun bentuk dasar Negara yang dipakai oleh suatu Negara tidak akan bernilai apa-apa tanpa ditindaklanjuti dengan penerapan dan pengamalan secara sungguhsungguh dalam kehidupan berbangsa dan bernegara. Baik oleh rakyat maupun oleh para penyelenggara Negara.
Tidak adanya kemauan menerapkan dan mengamalkan secara sungguh-sungguh dan konsisten, akan menghasilkan apatisme di kalangan masyarakat terhadap nilai-nilai dasar Negara tersebut. Sebaliknya jika ketidakmauan itu datangnya dari para elite politik dan penyelenggara Negara, maka keberadaan Pancasila akan tinggal menjadi slogan. Bahkan ketidaksungguhan itu pada gilirannya akan menyeret pada kecenderungan penyalahgunaan pelaksanaan dasar Negara sebagai alat untuk meletimasikan kekuasaan.

Pada masa Orde Lama, pemerintahan Presiden Soekarno diselenggarakan indoktrinasi operasionalisasi Pancasila dengan menyiapkan bahan yang dikenal sebagai "Tujuh Bahan Pokok Indoktrinasi." Tetapi dalam implementasinya malah menegakkan sistem politik demokrasi terpimpin yang dekat dengan kediktatoran ketimbang demokrasi Pancasila. Dengan demokrasi terpimpin itu Soekarno melakukan kebijakan-kebijakan politik yang tidak sesuai dengan prinsip-prinsip Pancasila.

Demikian juga dengan melihat realitas politik selama masa pemerintahan Orde Baru, kecenderungan rezim penguasa menjadikan Pancasila sebagai alat untuk melegitimasikan kekuasaannya semakin nyata. Atas nama Pancasila rezim ini melakukan kebijakankebijakan politik yang sarat dengan sikap otoriter. Namun demikian salah satu Kebijakan pemerintah dalam upaya melestarikan nilai-nilai Pancasila pada masa Orde Baru terlihat dengan dikeluarkan Ketetapan MPR No. II/MPR/1978 tentang Pedoman Penghayatan dan Pengamalan Pancasila. Harapan dari Ketetapan MPR tersebut adalah setiap warga negara dapat memahami hak dan kewajibannya serta bagaimana bersikap dan bertingkah laku dalam hidup bermasyarakat, berbangsa dan bernegara. Sementara itu melalui jalur pendidikan baik pendidikan dasar, menengah maupun tinggi diselenggarakan pendidikan 
dengan kurikulum yang berisi materi untuk meningkatkan kemampuan peserta didik dalam hidup menegara berdasarkan Pancasila.

Berdasarkan Ketetapan MPR Nomor II/MPR/1978, pemerintah dengan giatnya melakukan penataran Pedoman Penghayatan dan Pengamalan Pancasila (selanjutnya disingkat P4) kepada berbagai lapisan masyarakat mulai dari anak sekolah, mahasiswa, PNS, pengusaha sampai kepada pejabat. Saat itu sertifikat P4 layaknya "surat sakti". Seorang mahasiswa bisa ujian sarjana jika memiliki sertifikat P4 demikian juga seseorang ingin menduduki jabatan wajib memiliki sertifikat P4. Terlepas dari kepentingan penguasa saat ini tetapi jelas Penataran P4 telah mengakibatkan tersosialisasinya nilai-nilai Pancasila kepada masyarakat Indonesia, sekalipun semua usaha tersebut nampaknya belum dapat memberikan hasil sebagaimana yang diharapkan.

Pada masa reformasi sebagaimana diuraikan di atas negeri ini bak sebuah muara bagi semua ideologi dan pemikiran yg lambat laun justru bertolak belakang dengan ideologi pancasila itu sendiri. Masing-masing individu baik itu kelompok masyarakat hingga kalangan pejabat pemerintahan mengapresiasikan pemikiran-pemikirannya dari ideologi-ideologi yang mereka pahami dalam realitas kehidupan mereka masingmasing. masing-masing membentuk golongangolongan dan kelompok-kelompok sendirisendiri demi untuk mengkampanyekan ideologi-ideologi yang mereka yakini dan berusaha untuk mewabahi pikiran dan keyakinan masyarakat atas ideologi tersebut. Seperti halnya masing-masing individu dalam pemerintahan dengan kekuasaannya menerapkan ideologinya dalam kebijakankebijakan yang di ambil dan dibuat serta di terapkan ke masyarakat yg mengabaikan nilainilai pancasila. begitu juga dalam lingkungan sosial masyarakat dengan cara dan tatanan hidup yang juga semakin mengabaikan nilainilai Pancasila. terbukti dengan eksisnya kelompok-kelompok kiri dan kanan. fundamentalis, radikal dan liberal. semuanya saling bersaing dan mengikis serta mengaburkan nilai-nilai Pancasila yg menjadi pengikat perbedaan dan pemersatu bangsa.

Dari segi ekonomi misalnya juga belum dilaksanakannya nilai-nilai Pancasila dalam kebijakan ekonomi nasional. Hal itu ditegaskan oleh ekonom yang juga Rektor Universitas Islam Indonesia (UII), Prof Dr Edy Suandi Hamid MEc dalam diskusi Great Thinker seri ekonomi "Ekonomi Kerakyatan sebagai Basis Ekonomi Pancasila Belajar dari Prof Dr Mubyarto," di Sekolah Pascasarjana UGM. Dia menambahkan, banyak kebijakan negara yang arahnya bertentangan dengan prinsip-prinsip atau pilar-pilar ekonomi Pancasila, seperti dalam kebijakan impor beras, kenaikan harga BBM, kebijakan rekapitulasi perbankan, utang luar negeri dan sebagainya, serta praktik "markup" dan korupsi yang meluas di pemerintahan.

mengharapkan implementasi Pancasila dalam bidang ekonomi itu dilakukan oleh masyarakat luas, kalau kebijakan pemerintah dan petinggi pemerintah sendiri menyimpanginya. Kontekstualisasi dan implementasi Pancasila tidak bisa dilepaskan dari penegakkan perundangan yang berlaku, yang juga bersumber dari Pancasila tersebut.

Namun masalah besar yang masih harus dihadapi ialah bagaimana menjabarkan Pancasila sehingga dapat dijadikan pedoman dalam kehidupan nyata masyarakat di segenap aspek kehidupan masyarakat berbangsa dan bernegara. Hal tersebut amat diperlukan pada era reformasi saat ini, yang arahnya Pancasila nampak telah benar-benar dilupakan oleh berbagai kelompok dalam masyarakat, walaupun secara formal melalui ketetapan-ketetapan MPR-RI tetap diakui sebagai dasar negara yang harus dilaksanakan secara konsisten dalam kehidupan bernegara

Oleh karena itu bangsa ini dalam bertindak (terutama pemerintah) seharusnya 
\begin{tabular}{r|r|} 
J. Tjiptabudy, Kebijakan Pemerintah Dalam ..................... & 7 \\
Jurnal Sasi Vol.16. No.3 Bulan Juli - September 2010 &
\end{tabular}

sesuai dengan nilai-nilai Pancasila itu sendiri kalau bangsa ini masih menjadikan Pancasila sebagai landasan negara. Pancasila dijadikan dasar negara karena Pancasila merupakan suatu landaan yang sesuai dengan bangsa ini dan telah disetujui oleh seluruh rakyat Indonesia dalam sidang penentuan dasar negara.

Setiap sila-sila dalam Pancasila dewasa ini seharusnya masih dihayati dan dilaksanakan, bukan dilupakan dan dikesampingkan. Kebijakan-kebijakan pemerintah sekarang masih sangat jauh dari penerapan sila-sila Pancasila, namun sudah ada beberapa kebijakan yang mengarah kepada penerapan sila Pancasila, walau sedikit. Setiap sila dalam Pancasila kalau diteliti, kebijakan pemerintah masih sangat jauh dari penerapan nilai Pancasila.

Sudahkah pemerintah menjadikan Pancasila sebagai pedoman, sedikit Penjabaran.

Sila 1. Ketuhanan Yang Maha Esa: sudahkah pemerintah menggunakan sila pertama dari Pancasila ini. Apakah pemerintah sudah bersikap tegas dan cepat dalam menjamin warganya melaksanakan sila pertama ini yaitu hidup beragama dengan tenang tanpa ada kebingungan dalam menjalankan agamanya dari gangguan ajaranajaran yang menyimpang.

Sila 2. Kemanusian Yang Adil Dan Beradab: sudahkah pemerintah melaksanakan sila kedua ini. Apakah pemerintah sudah membuat peraturan yang di dalamnya dilandasi oleh sikap moral kemanusiaan tanpa adanya kepentingan golongan.

Sila 3. Persatuan Indonesia: sudahkah pemerintah melaksanakan sila ketiga ini. Apakah pemerintah sudah dapat mengatasi segala paham golongan, etnis, suku, ras, individu maupun golongan agama agar tidak dapat diruncingkan menjadi konflik dan permusuhan, tetapi menjadikan perbedaan itu persatuan yang menjadi kekuatan bagi bangsa ini.
Sila 4. Kerakyatan Yang Dipimpin Oleh Hikmat Kebijaksanaan Dalam Permusyawaratan / Perwakilan: apakah sudah terlaksana sila keempat ini. Apakah rakyat dipimpin oleh orang-orang yang bijaksana dalam mengambil keputusan bersama unutuk kepentingan masyarakat luas.

Sila 5. Keadilan Sosial Bagi Seluruh Rakyat Indonesia: apakah pemerintah sudah menjalankan sila kelima ini, apakah pemerintah sudah memberikan keadilan bagi setiap warganya baik berupa kesejahteraan, keamanan, bantuan, subsidi, serta kesempatan hidup tanpa adanya perbedaan hak.

\section{P E N U T U P}

Sampai detik ini, Pancasila masih merupakan falsafah, dasar negara, ideologi negara kita. Ini berarti kita percaya bahwa Pancasila sebagai sumber inspirasi dan sumber solusi atas permasalahan bangsa. Banyak kalangan yang menilai, kegagalan membangun negeri yang makmur disebabkan belum dilaksanannya amanat Pancasila. Berbagai persoalan bangsa yang muncul saat ini dinilai akibat pengamalan Pancasila dan UUD 1945 yang menyimpang. Karena itu, kalangan ini menyerukan kembali pengamalan Pancasila dan UUD 1945 secara kosekuen. Oleh karena itu mari kita renungkan sejenak, masih patutkah kita menyebut Pancasila sebagai dasar negara, kalau tidak dilaksanakan.!!! 
J. Tjiptabudy, Kebijakan Pemerintah Dalam .....................
Jurnal Sasi Vol.16. No.3 Bulan Juli - September 2010

\section{DAFTAR PUSTAKA}

As'ad Said Ali, 2009, Negara Pancasila Jalan Kemaslahatan Berbangsa, Penerbit LP3ES, Jakarta.

Kholid O. Santosa, 2004, Paradigma Baru Memahami Pancasila dan UUD 1945

- sebuah rekonstruksi sejarah atas gagasan dasar Negara RI, consensus nasional, dan demokrasi di Indonesia, Penerbit Sega Arsy, Bandung.

Midian Sirait, 2008, Revitalisasi Pancasila catatan-catatan tentang bangsa yang terus menerus menanti perwujudan keadilan sosial, Penerbit Kata, Jakarta.

Mubyarto, 1997, Ekonomi Pancasila Lintasan Pemikiran Mubyarto, Penerbit Aditya Medya, Yogyakarta.

http://fixguy.wordpress.com/artikel-pancasilariwayatmu-kini/

http://toraerdo.blogspot.com/2010/06/aktualisa si-pancasila.html

koranbogor.com, Yogyakarta 